\title{
Works of Moscow Art Workshops During the Reign of Tsar Fyodor Alexeyevich: Defining the Issue*
}

\section{N. V.Pivovarova}

State Russian Museum,

4, Inzhenernaya str., St. Petersburg, 191186, Russian Federation

For citation: Pivovarova, Nadezhda. "Works of Moscow Art Workshops During the Reign of Tsar Fyodor Alexeyevich: Defining the Issue". Vestnik of Saint Petersburg University. Arts 8, no. 4 (2018): 646-65. https://doi.org/10.21638/spbu15.2018.407

The paper presents the results of various studies of the works of Moscow Art workshops produced during the short reign of Tsar Fyodor Alexeyevich (1676-1682). It analyzes the creation, the iconography and the artistic features of a number of works of art from the collections of St. Petersburg and Moscow museums. Special attention is given to the iconographical programme and the inscription on the icon "The Crucifixion with apostles and saints" from the State Russian Museum in St. Petersburg. The icon's first and only researcher T. Ananyeva used the text of the inscription and the colour of the icon to interpret its worldly meaning as a work created for tsar Fyodor Alexeyevich to celebrate the end of the war and the establishment of peace. According to T. Ananyeva, the probable author of the inscription was Joann Maximovich, who sought Moscow's support in the period of struggle between Transdnieper and Turkey. However, a more recent study proved the version mistaken. It has been established that the text is not original, but is borrowed from the divine service of the feast of the Holy Cross Day (September 14). This, in turn, has called for reconsidering the iconographical programme of the icon. Support is given to the hypothesis that the icon is connected with the project of creating the "New Jerusalem" in the Moscow Kremlin under tsar Feodor Alexeevich. The paper presents the opinion that the icon was painted by a group of Moscow art workshop masters led by Mikhail Milyutin, chief painter of the Armoury Chamber. Two liturgical sets and a few altar Gospels from the domestic churches at the Grand Terem Palace in the Moscow Kremlin are also used in the current research. The features of technique are studied and differences in their design are established.

Keywords: Tsar Fyodor Alexeyevich, domestic churches, the Moscow Kremlin, Moscow art workshops.

The art created in the times of Tsar Fyodor Alexeyevich (1676-1682) comprises a short, yet an extraordinarily vibrant period in the formation of visual and applied arts. It was marked by a number of large construction undertakings, which encouraged the activities of Moscow's imperial workshops and led to the creation of different works and even whole compositions of art pieces, preserved until today by mere chance. They are now kept in several museum collections. In comparison to other museums, Moscow Kremlin Museums, the Hermitage and the Russian Museum possess by far the largest number of pieces and, moreover, the most impressive ones; in the Russian Museum, in particular, there are several icons and articles of wood-carving, but the more important pieces in

* The reported study was funded by RFBR according to the research project № 16-04-00258.

(c) Санкт-Петербургский государственный университет, 2018 
the museum collection are two sets of silver liturgical utensils and the Holy Testament that were Tsar Fyodor's contributions to the Kremlin churches. These works of art allow a closer look at the originality of art in the times of Tsar Fyodor Alexeyevich as well as at their connection to the artistic tendencies typical of earlier and later periods. They also pose the question of the extent the personality of the Tsar made an impact on the art of the late $17^{\text {th }}$ century.

There is a lot of research dedicated to the reign of Tsar Fyodor [1-3 and others], but only a few art history articles make an attempt at analysing the works of art that appeared in the late 1670s and the early 1680s in connection with the history of Tsar Fyodor's reign in general or at tying those to different events in his life. His "New Jerusalem" project in the Moscow Kremlin, in which several of the Tsar's terem churches $[4 ; 5]$ were rebuilt and given a new dedication, is seen in the literature as a display of his particular piousness; while the appearance of such works as "The Crucifixion" icon (now kept in the Russian Museum) and a large wooden triptych carved by Kiev craftsmen representing the saint warrior Theodore Stratelates, who holds the same name as the Tsar, surrounded by a composition of saints and festivities [6-7; 8, p. 19-20, 41, 78-95. Cat. 3], (Moscow Kremlin Museums) is connected to the achievements in foreign affairs.

Researchers believe that the young Tsar, who took the throne at the age of 14, was especially religious due to both the state of his health and the influence of people close to him, in particular his pious aunt, Tsarevna Tatyana Mikhaylovna. It was her stories about the Church of the Holy Sepulchre in the New Jerusalem Monastery founded by Patriarch Nikon that not only motivated the young Tsar to resume the construction, but also contributed to his idea of a "New Jerusalem" in Kremlin taking shape [4, p. 55].

Fyodor started to bring his plan to life in the spring of 1678 - the earliest records of this found in the documents of the Kremlin Armoury mention that the Sepulchre and 60 alabaster cherubs would be placed "upstairs". The construction continued in 16791680 when the paintings portraying "The Passion of Christ" were created and two cypress crosses were carved, one was meant to be placed "behind the throne" of the Church of the Holy Righteous Martyr Eudokia of Heliopolis, while the other was put at Golgotha [4, p. 56-7].

In the spring of 1681 a church in the name of the Exaltation of the Holy Cross, more commonly called 'the Church of the Crucifix', was constructed in the choir of the renewed Church of the Holy Righteous Martyr Eudokia; in the summer of the same year the Tsar decided to re-consecrate the Church of Eudokia. Since then it has been called the Church of the Resurrection of Christ [4, p. 58 $]^{1}$. As noted by I. M. Sokolova, who studied the complex of the New Jerusalem Monastery, "the design of the Church of the Exaltation of the Holy Cross together with the already existing Golgotha with the Sepulchre and the re-consecration of the Church of Eudokia in the name of the Resurrection of Christ obviously marked Jerusalem's sacred topography inside the Kremlin palace" [4, p.59]. Let us take a look at another element of the church design, with the unity of two themes specially accentuated: Passions, culminating in the Crucifixion, and the Resurrection of Christ. We believe that the originality of that idea may be projected onto the design of one of the icons that was created during the reign of Tsar Fyodor III of Russia and that is now kept in the collection of the Russian Museum.

${ }^{1}$ The consecration of the church took place on $15^{\text {th }}$ December, 1681, although the Tsar had already attended the liturgy on $6^{\text {th }}$ August [4, p. 58]. 


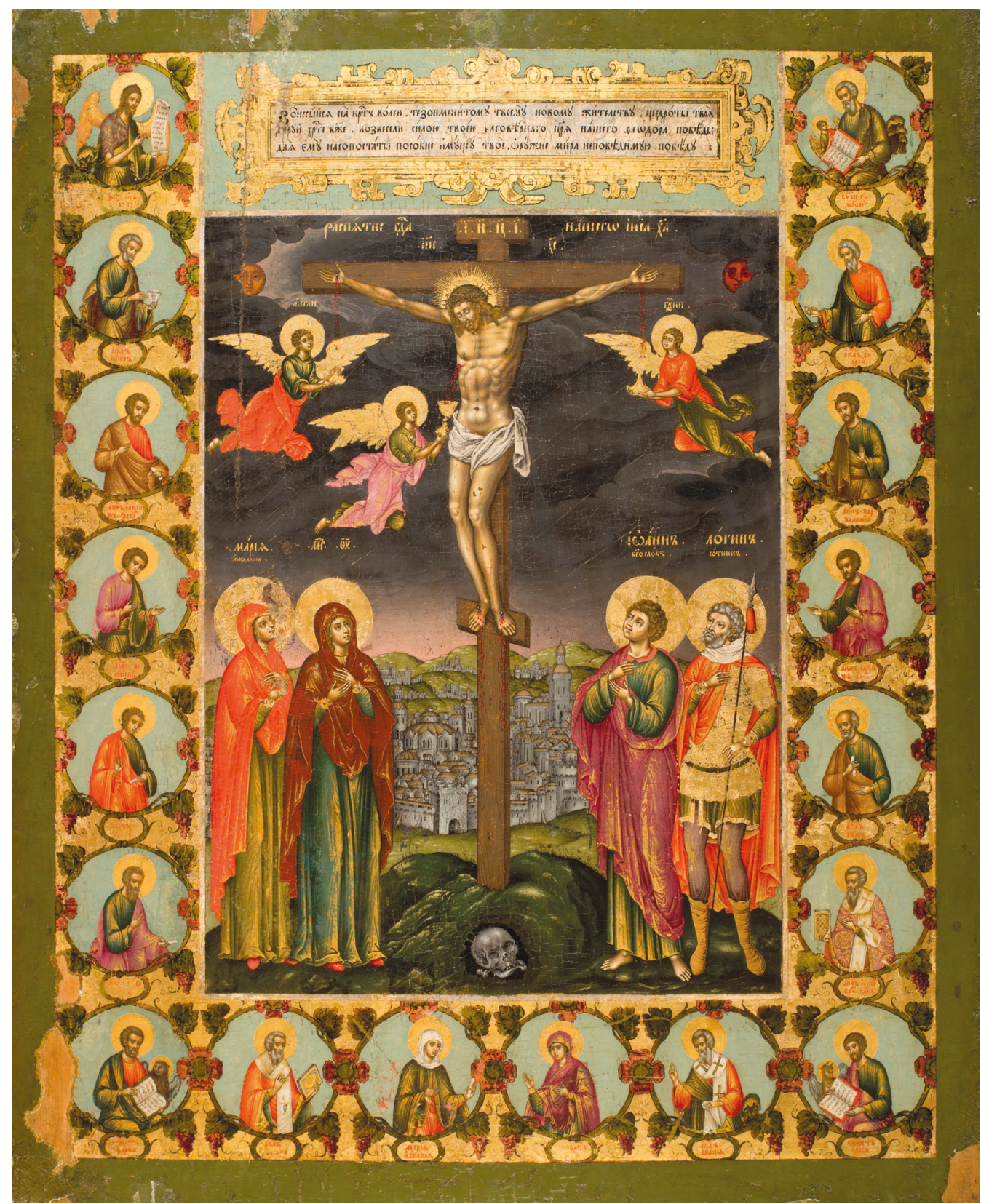

Fig. 1. “The Crucifixion”. Circa 1681-1682. Moscow Kremlin Workshops. State Russian Museum

There is no doubt that the image "The Crucifixion" (fig. 1) is one of the masterpieces in the collection of late Russian icon-painting ${ }^{2}$, although, quite surprisingly, there is only one short article, published 40 years ago, that discusses the piece [6]. It mainly describes the

2 State Russian Museum, Inv. No. ДРЖ-2365. Wood (plank without a shrine), two blind single-sided timber connectors, primer, tempera. $78 \times 63 \times 3,5 \mathrm{~cm}$. Date of entry not established. 
artistic qualities of the icon, which is characteristic of art history of the Soviet period. Nevertheless, based on the inscription at the top of the icon, T. A. Ananyeva, the author of the article, remarked that the text "reflects joy due to establishing a long-lasting state of peace and liberation from the pains of the war" and explains "the true, earth-bound meaning" of the icon [6, p. 332]. The researcher did not specify the source of the inscription, but she noted its "solemn clerical nature" and suggested that it may have been written by a clergyman of high standing, who commissioned the icon [6, p.330]. It is clear from the references that T. A. Ananyeva leant toward the idea that this person "could be John Maximovitch, later the Metropolitan of Tobolsk, who in 1679 travelled to Moscow to call for help for Transdnieper Little Russia, impoverished by Turks. He is known for describing life history of Saints and Fathers of the Desert in syllabic verses (italics. - N.P.) [6, p.332, note 4].

A closer look at the inscription makes us question the suggested hypothesis as the text does not belong to the original works of "clergymen of high standing" of the $17^{\text {th }}$ century, but makes up a part of the liturgical following at the Feast of the Cross (14 September, Old Style):

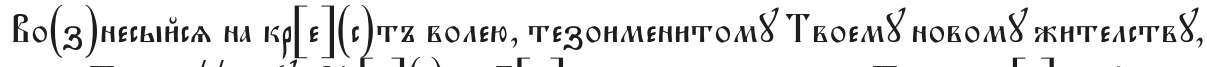

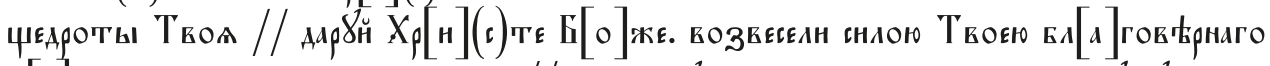

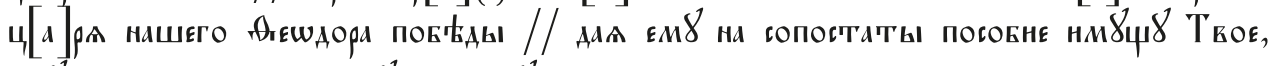

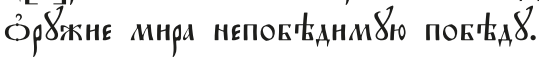

The text above, Kontakion ( $4^{\text {th }}$ Tone) at the Feast of the Universal Exaltation of the Precious and Life-Giving Cross, has been preserved as part of the divine service to the present day; it can be heard in the churches on 27 September of every year [9, p. 421]. The omission of the Tsar's or the Emperor's name is typical of contemporary recitations ${ }^{3}$, however, the name used to be an obligatory part of the divine service in the $17^{\text {th }}$ - early $20^{\text {th }}$ century. Professor M. Skaballanovich compared the Slavic text of the Kontakion with its Greek equivalent and delivered its textological analysis; he found out that in contrast to the Troparions of a feast rite, the Kontakion especially mentions both the Crucifixion and the Cross, which is a "weapon of peace" and an "unconquerable sign of victory". "For Christ's 'life, i.e. His (Christ's. - N. P.) people, His legacy, - Skaballanovich wrote, - the Kontakion does not only seek to rescue, bless and save it, like a Troparion, but it seeks mercy; the Emperor does not only ask for victory, but also "the delight of God's power", special military achievements" [10, p.78-9]. It is clear that the text is ambiguous enough and should not be interpreted literally, as was the case in the article by T. A. Ananyeva.

Explaining the cross as a sign of victory over the enemies stems from the core meaning of this Christian symbol: the cross is the torture tool of Our Saviour and at the same time the means of Atonement. It is believed that this idea captures the main points of the icon in the collection of the Russian Museum.

The centrepiece of the icon shows "The Crucifixion", the dramatic final episode of the earthly life of Our Saviour. Nailed to the cross, Jesus Christ is in the foreground; the dark cloudy sky in the background throws a shadow on the hills and the buildings of Jerusalem. Jesus is depicted wearing a crown of thorns, his head leaning onto his right shoulder, his eyes closed. His body is slightly turned to side; blood is dripping from his wrists, feet and ribs, pierced by

3 The words "our faithful king" were changed to the neutral formula "Your faithful people", and the singular masculine pronoun, $3^{\text {rd }}$ person, "him" - to the plural form, $1^{\text {st }}$ person, "us". 


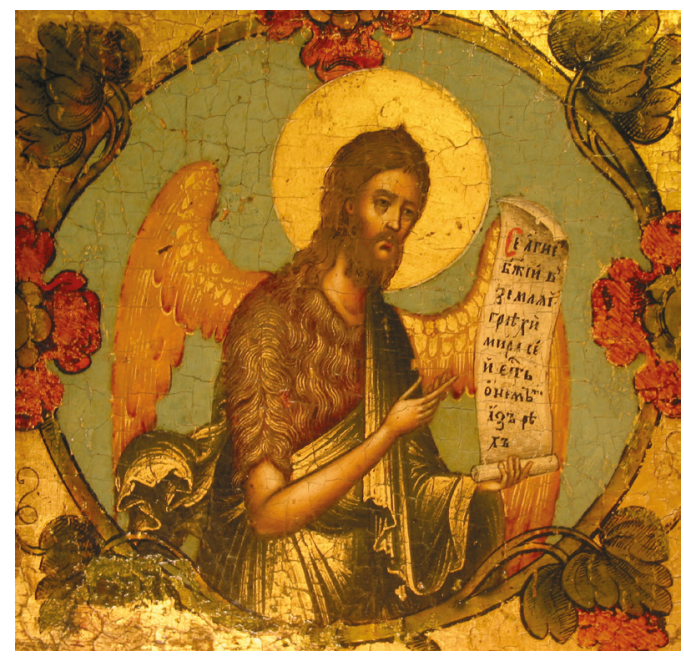

Fig. 2. John the Baptist - "The Crucifixion" (detail). Circa 1681-1682. Moscow Kremlin Workshops. State Russian Museum

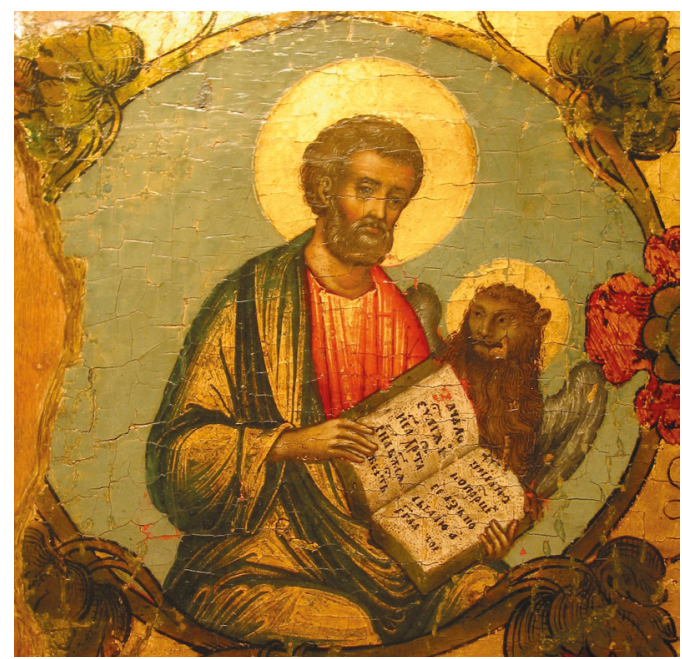

Fig. 4. Mark the Evangelist - "The Crucifixion" (detail). Circa 1681-1682. Moscow Kremlin Workshops. State Russian Museum

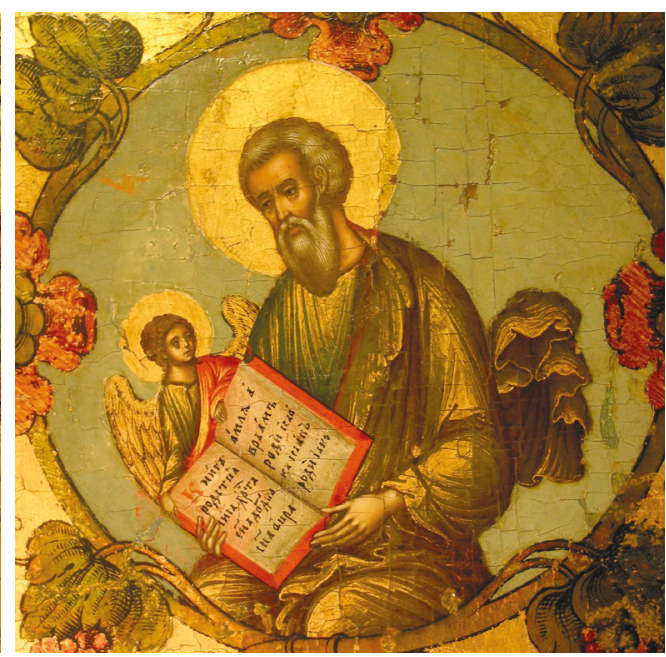

Fig. 3. Matthew the Evangelist - "The Crucifixion" (detail). Circa 1681-1682. Moscow Kremlin Workshops. State Russian Museum

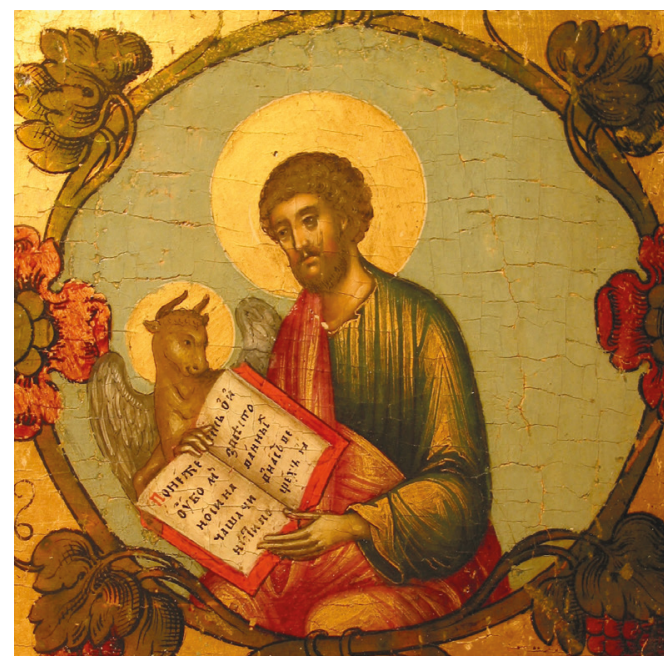

Fig. 5. Luke the Evangelist - "The Crucifixion" (detail). Circa 1681-1682. Moscow Kremlin Workshops. State Russian Museum

the nails. Standing before him on either side of the Crucifix are the Virgin Mother and Mary Magdalene, St. John the Evangelist and the centurion Longinus. The traditional composition is finished with images of flying angels, collecting Christ's blood into golden vessels.

Traditionally "The Crucifixion" was part of the festivities depicted in the iconostasis that reflected the chronology of the events in the Holy Testament, including Passions and the Resurrection of Christ. Despite the fact that the icon in question has the typical parameters for "festivities", such as size and format, it was created as an independent image, judging by the specifics of its iconography. 
The centrepiece with the Crucifixion is surrounded by medallions with images of saints. In the corners we can see St. John the Baptist (fig. 2) ${ }^{4}$ and the evangelists Matthew, Mark and Luke (fig. 3-5). (The fact that John the Apostle is not pictured among other evangelists is explained by his presence in the centrepiece where he stands before the Cross). The opened books that Matthew and Luke are holding show texts, traditional for the evangelist iconography, that go back to the initial stanzas of their Gospels: "The book of the genealogy of Jesus Christ, the son of David, the son of Abraham. Abraham was the father of Isaac, Isaac the father of Jacob" (Matthew 1: 1-2); "Inasmuch as many have undertaken to compile a narrative of the things which have been accomplished among us" (Luke 1: 1).

Grouped in columns on either side of the centrepiece are pairs of apostles: Peter and Andrew, James, son of Zebedee, and Bartholomew, Philip and James, son of Alphaeus, Thomas and Simon the Canaanite, Judas Thaddaeus and James, brother of Jesus. Only one of them - Peter the Apostle - is depicted holding a slightly opened scroll that shows a text of exceptional importance to interpreting the idea behind the icon: "You are the Christ, the Son <of the living God>" (Matthew 16: 16). The fragment above is a citation from the Gospel of Matthew and serves as Peter's answer to Christ's question "Who do you say I am?" (compare: John 6: 69; Mark 8: 29; Luke 9: 20).

Half-length portraits of saints are placed in the bottom row, between the evangelists; they are grouped in pairs and arranged from margins to centre: Cleopas, brother of St. Joseph, and Ananias, as well as Myrrhbearers - Mary of Cleopas and Salome.

Therefore, the icon shows 15 apostles (ten of the twelve apostles and five of the 70 apostles) and two Myrrhbearers as witnesses of the Saviour's earthly life and resurrection (fig. 6-7). According to the Holy Testament, Mary of Cleopas and Salome, together with the Virgin Mother and Mary Magdalene that stood before the Cross, found the tomb of Jesus empty and were among the first to discover that He had been resurrected (Mark 15: 40, 16: 1). Including theirs images in the same row with Cleopas the Apostle, one of Christ's two disciples who witnessed His resurrection, is deeply symbolic. Like the Myrrhbearers, he and Luke, Christ's companions on his way to Emmaus, were destined to recognize their resurrected Teacher in the "stranger" (Luke 24: 13-32).

The main idea behind the icon is built on the concept of inseparable unity of the Passions and the Resurrection of Christ. It is no coincidence that the row of apostles starts with John the Baptist, the last among the prophets and the first among the apostles who brought the news of the salvific mission of Jesus Christ. The text of his prophecy is also part of the unfolded scroll: "Behold, the Lamb of God, who takes away the sin of the world! This is he of whom I said..." (John 1:29-30). At the same time, the text from the opened book that Mark is holding refers to John as God's Forerunner: "The beginning of the gospel of Jesus Christ, the Son of God. As it is written in Isaiah the prophet, "Behold, I send my messenger before your face" (Mark 1: 1-2).

The medallions with images of the apostles are wickered in grapevine, reminding us of the words the Saviour said to the apostles: "I am the true vine, and my Father is the vinedresser... I am the vine; you are the branches" (John 15: 1, 5). The vine has been considered a symbol of Our Saviour's sacrifice from ancient times.

4 T. A. Ananyeva considered the image of John the Baptist to be patronal for the customer, presumably, John Maksimovich [6, p.332, note 4]. 


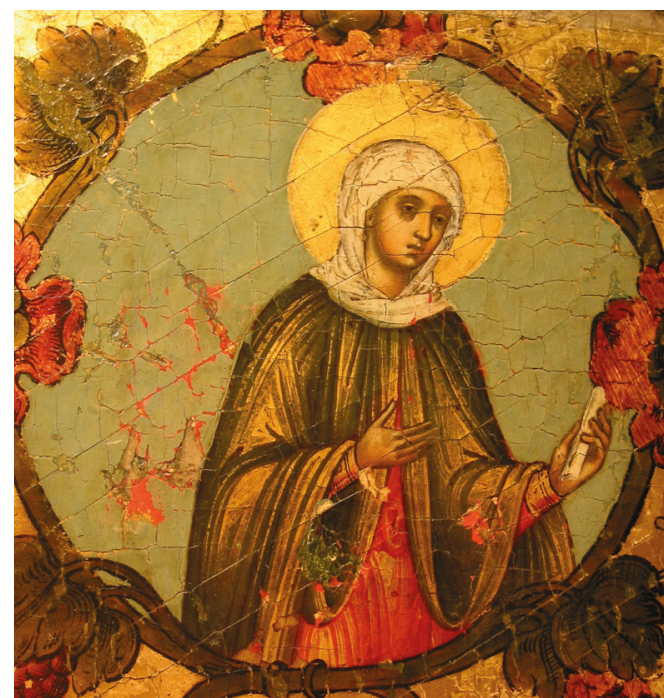

Fig. 6. Mary of James - "The Crucifixion" (detail). Circa 1681-1682. Moscow Kremlin Workshops. State Russian Museum

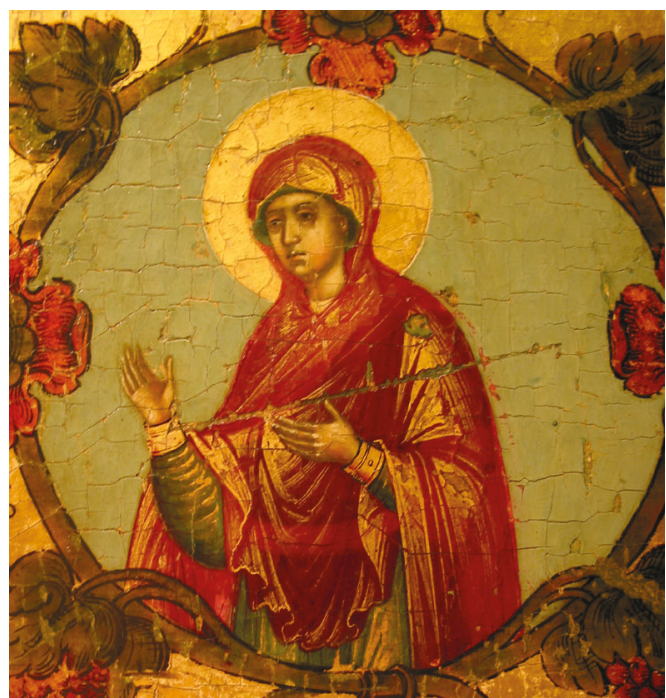

Fig. 7. Salome - "The Crucifixion" (detail). Circa 1681-1682. Moscow Kremlin Workshops. State Russian Museum

As it can be seen from the stylistic features of the icon, it was created by a group of artists of the Kremlin Armoury under the guidance of the icon painter Mikhail Milyutin 5 . His artistic device and particular traits of his style ${ }^{6}$ eloquently reveal themselves in two of his signed paintings from the 1680s: the icon of St. Alexius, Metropolitan of Kiev (1688, the Russian Museum) and the image of the patron saints of Tsar Fyodor Alexeyevich and Tsaritsa Agafya Semyonovna from the Assumption Monastery in the Alexandrov Kremlin (1681, State Historical Museum) [14, p. 346-9, Cat. 86; p. 342-3, Cat. 84]. A distinctive feature of Milyutin's style, who was an inimitable drawing artist and an outstanding colourist, is his impeccable command of the mimetic writing technique (fig. 8-11), based on the thorough knowledge of human anatomy. At the same time, the individual trait of his style is the use of linear stylization when working on "personal" details, deliberate exaggeration of facial features and the artificial "aging" of the image of even young characters. Such details as deep wrinkles spreading out in the shape of a fan, a "fork" on the bridge of the nose and furrowed eyebrows allow the painter to enhance the psychological characteristics as well as to reveal the dramatic nature of the event, which to the fullest extent corresponds to the content of the composition "The Crucifixion", but these details are also appropriate for icons with images of saints. Another similarity between "The Crucifixion" and the icon of the Great Martyr Theodore Stratelates and the Martyr Agafya is the special interpretation of ball-shaped earth, formed by a group of gently sloping hills that lack rock-mounds traditional for classic icon-painting.

${ }^{5}$ More about the painter [11; 12, p. 414-8].

6 The closest analogy to the icon in the Russian Museum is Mikhail Milyutin's signed icon "The Crucifixion" from the festivities row in the iconostasis of the Cathedral of the Archangel in the Moscow Kremlin (1681). See: [13, p. 237, 255, note 73; 14, p. 336, note 1]. However, we believe that this closeness only shows in the general composition; it is not easy to talk about Mikhail Malyutin's style and device due to late restoration works that distort the original author's painting on the icon of the archangel. 


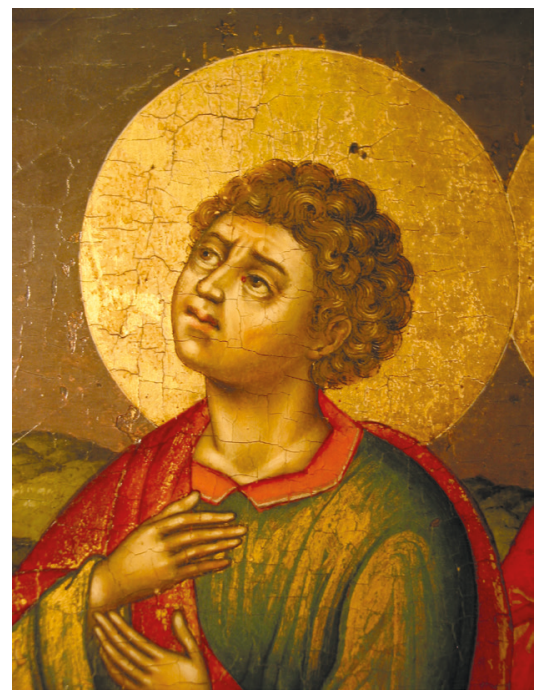

Fig. 8. John the Apostle - "The Crucifixion" (detail). Circa 1681-1682. Moscow Kremlin Workshops. State Russian Museum

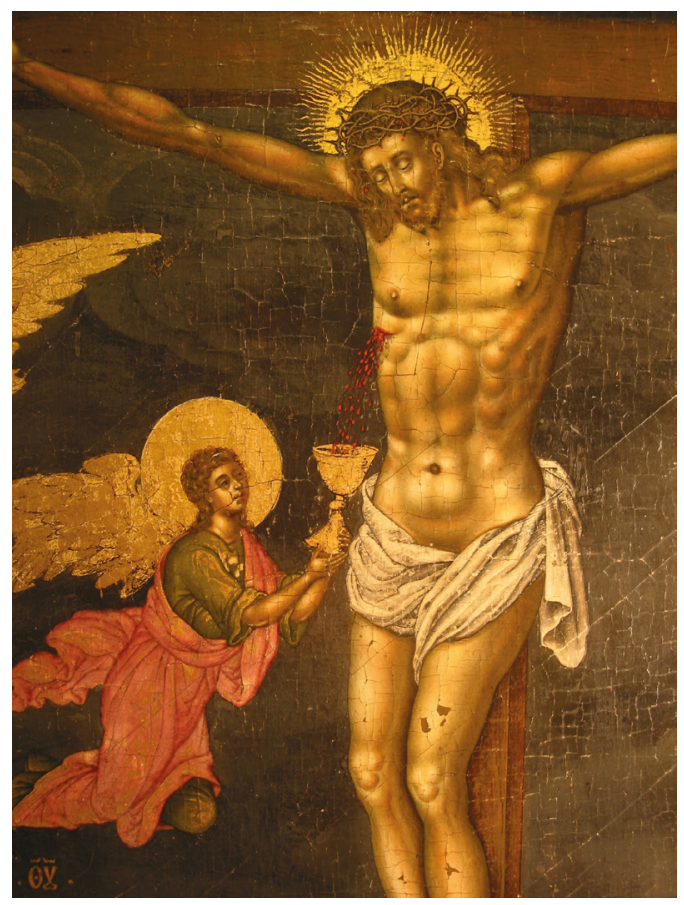

Fig. 11. Our Lady and Mary Magdalene - "The Crucifixion" (detail). Circa 1681-1682. Moscow Kremlin Workshops. State Russian Museum

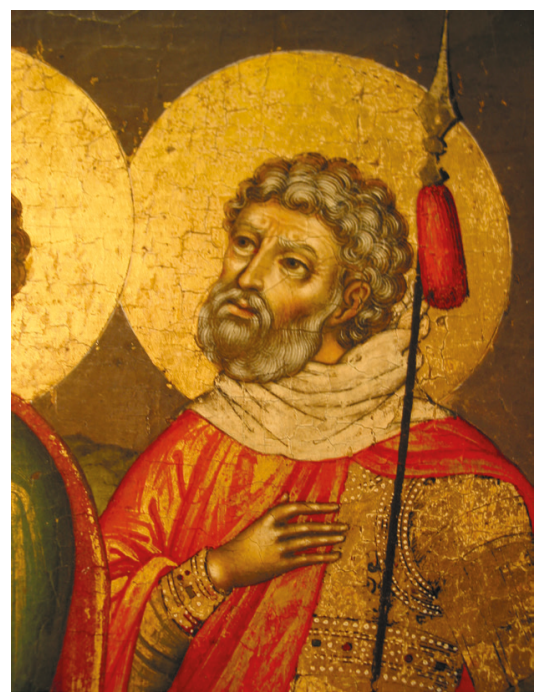

Fig. 9. Longinus - "The Crucifixion" (detail). Circa 1681-1682. Moscow Kremlin Workshops. State Russian Museum

Fig. 10. Jesus Christ - "The Crucifixion” (detail). Circa 1681-1682. Moscow Kremlin Workshops. State Russian Museum

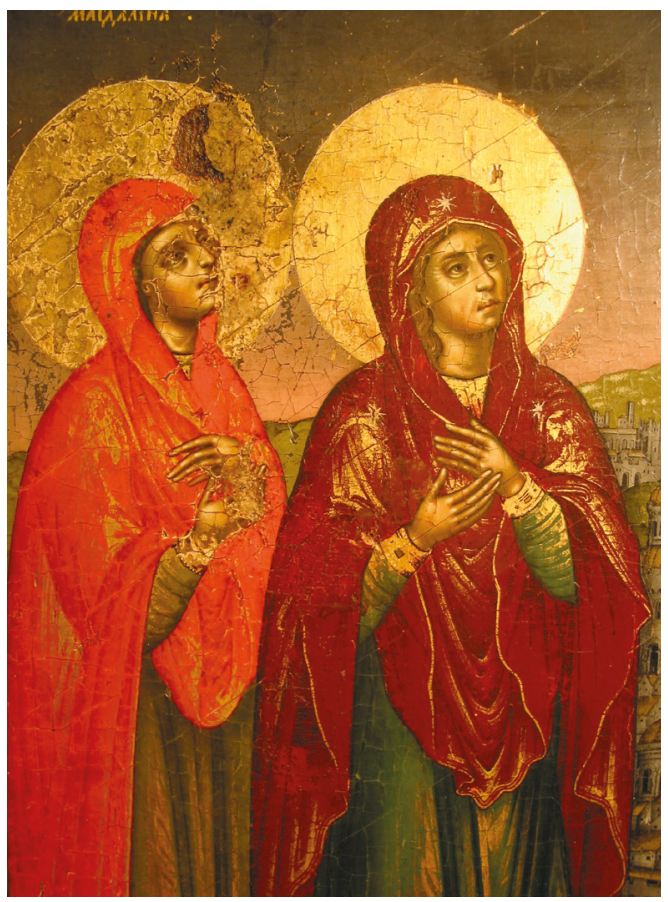


The faces of the saints framing the centrepiece are executed in a different manner and lack distinctive psychological characteristics. They are not so voluminous and carry the imprint of a certain craftsmanship. This allows us to assume that at least two icon painters took part in creating the icon; if we consider the inscriptions introduced into the iconic structure of the icon, even three masters may have worked on the piece, including the one who made the inscription?

From this perspective, the iconography and the style of the icon suggest that it could be created for Tsar Fyodor Alekseyevich; however, as T. A. Ananyeva believed [6, p. 330], the reason for making the icon was not political, as Tsar Fyodor concluded a 13-year truce with Poland in 1678 and a 20-year truce with the Crimean Khan in 1681, but the icon was created during the reconstruction of the Tsar's terem churches. Its plot, the specifics of its composition and the contents of the inscription match the dedication of the "upper" churches (a single complex consisting of the Church of the Resurrection and the Church of the Exaltation of the Cross, or the Crucifixion, surrounded by Jerusalem realia: Golgotha and a variation of the Holy Sepulchre). The fact that our icon used to be placed in one of these churches has not yet been proved by documentary evidence. It is clear from the existing publications that there were two images of the same name in the interior of the terem church of the Crucifixion: one in the church itself, the other in the altar behind the throne [16, p. 59-60]. Unfortunately, it is not possible to give more specific information about the iconography of these icons.

In 1930 the collection of the Russian Museum received two sets of silver liturgical vessels from the State Hermitage. Each consisted of five objects: a chalice, a paten (discos), a star (zvezditsa), and two plates. As it became clear from the documents, the sets were taken to the Hermitage in 1922 as part of the liturgical utensils intended for sale to help the hungry ("pomgol"). Among the works of church art, saved from being sold in exchange for food, there were items made of precious metals such as liturgical vessels, the settings of the Gospels and icons, crosses, candlesticks, etc., selected by the "pomgol" committee in the churches of St. Petersburg. The inscriptions preserved on the vessels and the published information about them made it possible to establish the origin of the vessels from the above-mentioned "upper" churches - the Church of the Resurrection and Church of the Crucifixion of the Lord in the Moscow Kremlin [17; 18, p.223-7]. The foundation of a new capital on the banks of the Neva led to the relocation of the vessels to St. Petersburg. It was here that the objects became separated and can now be found in different churches: in the Trinity Cathedral on the Petersburg Side and in the Grand Church of the Winter Palace ${ }^{8}$.

The dates carved on the chalices from the Kremlin churches - the Church of the Resurrection (fig. 12) and the Church of the Crucifixion (1678 and 1681) ${ }^{9}-$ and on the

7 The hand of the extraordinary calligrapher who performed the inscription in the cartouche over the centrepiece may be identified on some icons from the collection of the Moscow Kremlin Museums. Among them is the image "The Crucifixion and Martyrdoms of the Apostles" by the isograph Fyodor Rozhnov 1697-1699 [15, ill. 3-5].

${ }^{8}$ In the $18^{\text {th }}$ century two sets of "golden vessels" were moved to St. Petersburg from Moscow - from Spasskaya (1677) and Voskresenskaya (1679) churches. From that time they have been kept in the Grand Church of the Winter Palace (now the State Hermitage). As it was established through a detailed study of the vessels, after being transported to St. Petersburg the vessels were separated, which is explained by their extraordinary similarity. See about them [19; 20; 21, p. 294-8, No. R-51, 52; 22, p. 85, cat. 106].

9 State Russian Museum, Inv. No. БК-3466, БК-3002. Size: height - 29,3; d of the cup - 17,3; d of the foundation - 18,9; height $-30,4$; $\mathrm{d}$ of the cup $-17,0$; $\mathrm{d}$ of the foundation $-19,7$. The first of the chalices was in the Trinity Cathedral on the Petrograd Side in St. Petersburg, while the second was in the Cathedral of the Image of the Saviour Not Made by Hands in the Winter Palace. 
paten from the Church of the Crucifixion $(1681)^{10}$ are evidence that the sets of liturgical utensils were created at the same time as the "upper" churches were reconstructed upon the initiative of Tsar Fyodor of Russia.

The vessels are made of silver in the technique of coining, forging and engraving; they are covered with black and gold. The properties they possess, such as form and decorative design, are characteristic of the $17^{\text {th }}$ century. Also typical of that time are the set-in inscriptions containing dates of manufacturing, place of contributing, the name and the title of the Tsar. The decor of the vessels consists of traditional elements: a seven-figure Deesis is depicted on the cups of the chalices. The figures of Christ, the Virgin, John the Baptist, the archangels Michael and Gabriel, the apostles Peter and Paul are enclosed in oval medallions with magnificent golden frames. The back of the chalices shows the Golgotha cross in similar medallions.

The plates of the paten, decorated with the composition "Behold, the lamb...", are fixed onto open-work pierced pallets with the symbols of the evangelists. Carved on the bottoms of the plates are the compositions "The Golgotha Cross" and "Our Lady of the Sign".

Liturgical inscriptions play an important role in the decoration of the vessels. On the chalices they are carved on the crowns of the cups: "Drink ye all of it..."; on the paten the inscriptions are situated on the sides of the plates: "Behold, the Lamb of God, who takes away the sin of the world!" The inscriptions on the plates reproduce the prayers to the Cross and the Virgin Mother: "Before your cross, we bow down in worship, O master, And your holy resurrection we glorify!"; "I trust in thee Mother of God, save and protect me".

Another important element in the decoration of the vessels is the ornamental motif; first and foremost, it is a sprout with large buds and lush flowers. This ornament is used on the chalice standings, around the plate bottoms and on the arcs of the stars. The scenes of the Passion of the Lord and the passion emblems are notably absent on the vessels, but from the time of Fyodor Alekseyevich they gradually became part of traditional decoration on liturgical utensils.

${ }^{10}$ State Russian Museum. Inv. No. БК-3013. Height - 12; d of the cup -26,0; d of the foundation 13,5. The discos is in St. Petersburg, in the Trinity Cathedral on the Petrograd Side. 


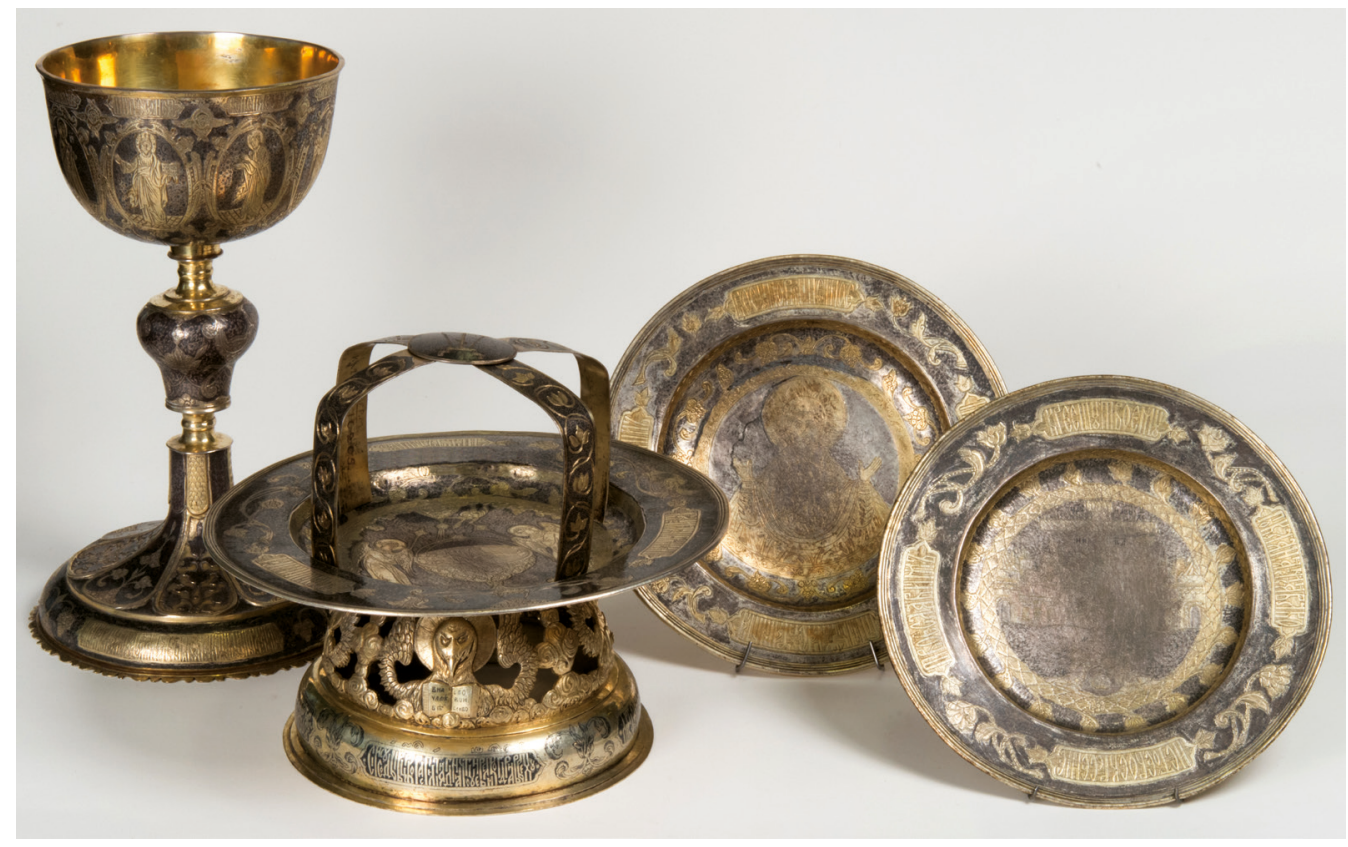

Fig. 13. Liturgical set, Church of the Crucifixion of the Lord. 1681. Moscow Kremlin Workshops. State Russian Museum

Despite the striking similarity of the sets, each of them possesses its own individual characteristics. The 1681 set (fig. 13) stands out thanks to a stronger decorative beginning: there is more gilding and the black surfaces are heavily filled with images and ornaments. Some details of the images on the vessels have also been given a new interpretation. Thus, the neutral inscription "father", inscribed on the swirling clouds at the top of the composition "Behold, the lamb..." (paten of 1678) on the paten of 1681 gives way to the image of Lord Sabaoth, and the symbols of the evangelists on the palette of this discos are depicted with the opened codices.

The study of the four plates allowed to establish that two of them certainly belong to the set of the Church of the Resurrection and, thus, can be dated $1678^{11}$. The decorative elements on their bottoms are identical in design with the rest of the set's items. At the same time, the two other plates do not only have individual decor features, but also differ in weight and size ${ }^{12}$. This means that initially they were not intended for the Church of the Crucifixion and were only transported there later together with other miscellaneous utensils.

11 State Russian Museum, Inv. No. БK-3008 (plate with the Golgotha cross). Height. $-1,9 ; \mathrm{d}-23,0$; Inv. No. БK-3009 (plate with the Virgin Mother "The Sign"). Height. - 1,7; d - 22,5. In St. Petersburg the plates were in the Trinity Cathedral on the Petrograd Side.

12 State Russian Museum, Inv. No. БK-3007 (plate with the Golgotha cross). Height. - 1,8, d - 22,4; Inv. No. БK-3006 (plate with the Virgin Mother "The Sign"). Height. - 2,6; d - 23,1. In St. Petersburg the plates were in the Cathedral of the Image of the Saviour Not Made by Hands in the Winter Palace. 
Four months after the completion of the set for the Church of the Crucifixion, a water-sinking bowl was placed by Fyodor Alexeyevich in the Church of the Resurrection ${ }^{13}$. This is evidenced by the inscription performed on her crown: $d \mathrm{KT}$ T , 3Pप $(7190=1681)(\mathrm{r})$

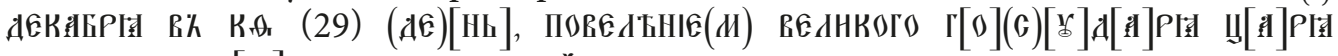

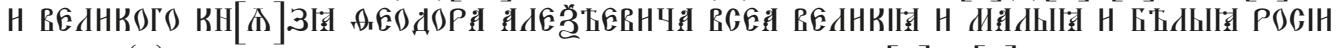

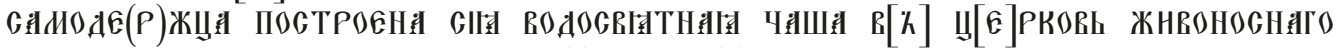

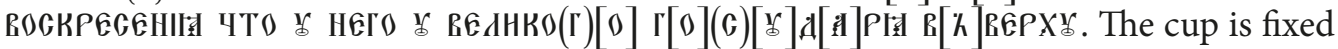
onto a low pallet and has two cast facetted handles. Inside the vessel there is a gilded target with the composition "The Golgotha Cross", typical of this type of vessel. The closest analogy to the vessel is a water-bearing cup "built" by the order of Fyodor Alexeyevich on $7^{\text {th }}$ February, 1682, in the Nilov Stolobensky Monastery ${ }^{14}$.

The sets of liturgical utensils for the Church of the Resurrection and the Church of the Crucifixion were created by the best masters of the Silver and Gold Chambers of the Moscow Kremlin where both Russian and foreign craftsmen worked side by side. The technique used for creating the vessels was not innovative for the reign of Tsar Fyodor Alexeyevich. It was also used by the masters during the reign of Alexei Mikhailovich, and under Tsar Fyodor's successors, Tsars Ivan and Peter Alexeyevich. This is evidenced by several secular vessels kept in the collection of the Russian Museum. The earliest among them was the 'stavets' (a silver plate) of Tsarevich Fyodor Alexeyevich, executed between 1661 and $1676^{15}$, the latest are the mug and the bottle that belonged to Tsarevich Alexey Petrovich (1690s) ${ }^{16}$.

The particular trait of the technique in which all of the listed items were executed consisted in the following: small black etchings were drawn on the matte metal surface of products, against their background the carved gilded images and ornaments loomed very clearly. This combination of a muffled background and precious gold planes, emitting light, gave the articles an exceptionally festive appearance. At the same time, the use of these techniques made it possible to neutralize the blinding shine of gold which inevitably arose when the external surface of the silver vessel was gilded.

Articles in this technique were made not only for personal use by members of the royal home or for their contributions to churches. They were also popular among the representatives of the nobility, as evidenced by the description of similar items made in 1693 by the order of Prince Yakov Nikitich Odoevsky, and in the first quarter of the $19^{\text {th }}$ century as well as those donated by Prince Dmitry Nikolaevich Sheremetev to the Nikolayevskaya Church in the state-owned Lizhimskoy district of Petrozavodsk Uyezd and to the Globitskaya Church of the Voronitskaya Myza. The source mentions a chalice, a sacramental spoon, a discos and the rim of the asperse cup, "silver, gilded with black", which makes it possible to recognize in the text of the document objects executed in the technique of interest to us [I, p. 54, 7 vol.].

13 State Russian Museum, Inv. No. БK-3016. Height. - 19,2; d of the cup - 43,4; d of the foundation $-24,5$. In St. Petersburg the cup was in the Trinity Cathedral on the Petrograd Side.

14 Tver State United Museum, Inv. 1064. Height. - 17,5; d of the cup - 44. See: [23, p. 17, cat. 14].

15 State Russian Museum, Inv. No. БK-3149. Silver; forging, casting, blackening, carving, gilding. $7.1 \times 11.3 \times 9$. The 'stavets' comes from royal property. The time of its appearance in St. Petersburg has not yet been established. It has been moved to the Russian Museum from the State Hermitage in 1939; it used to be in the Arsenal of Tsarskoye Selo. See: [24, p. 154-5, ill.].

${ }^{16}$ Entered the Russian Museum through the State Hermitage in 1939; previously transferred from "Gokhran" through the Kremlin Armoury. Published: [25, p. 196, cat. 72, 73, ill. 80-81]. 
It may have been thanks to Tsar Fyodor Alexeyevich that a new typology of the Holy Gospels' settings appeared and spread. Up to now, several copies of the codices that the Tsar placed in the Kremlin churches remain intact, as well as samples of settings of a later period that the typology developed in his reign. The plates of the setting that were attached to the upper and lower binding boards were made of gold and covered with a plant pattern, executed in the technique of stamping and engraving. Traditionally, in the middle of the upper cover there was an embossed Crucifixion or a composition of a three-figure Deesis with the Saviour on the throne in the centre; in the corners there are images of the four evangelists with their symbols. For figurative images artists used the technique of painted enamel on embossed surfaces. It was this technique that, along with other technical and iconographic features, became the signature of a new setting type. In addition to the precious stones encrusted into the upper lid and fixed in its background areas, artists in the times of Tsar Fyodor Alexeyevich began to introduce small additional plates with "Passion emblems" as part of decoration; these emblems are images of the tools used to torture Our Lord: spears, canes, a crown of thorns, a purple mantle, a pillar, nails etc. Later on, artists added plot compositions depicting the final dramatic episodes of the Saviour's earthly life or even replaced "Passion emblems" with the new compositions.

The earliest examples of the settings of this type are now stored in the Moscow Kremlin Museums. Like many of the works mentioned in this paper, they were made during the renovation of the terem churches. The setting of the Holy Testament for the Church of the Saviour of the Holy Face of the Moscow Kremlin (fig. 14) was created in 1678 by a group of royal masters, Mikhail Vasiliev, Iona Semidel, Yuri and Stepan Nyrin Goliash, Christian Kreimer, Dmitry Terentiev, Yuri Filimov Frobos. Its upper cover is decorated with a composition of a three-figure Deesis, around which there are "Passion emblems" placed on eight oval enamel plaques, and in the corners there are four curved corner pieces with the evangelists. At the bottom of the lid there is another similar oval plaque with the composition "Entombement" [26, p. 130-1, cat. 122]. The inscription with the name of the depositor, the date and place of the deposit is placed on the face of the bottom board.

The second Gospel, which Fyodor Alexeyevich put into the Church of the Resurrection, is dated the same year. The same masters took part in creating the second Gospel, their "handwriting" becomes obvious when compared with the setting of the Spassky Cathedral. The centrepiece here is the composition "The Crucifixion" with four forthcoming pieces [26, p.132-3, cat. 123], positions, gestures and even the drawing of their clothes resemble similar figures on the icon "The Crucifixion", discussed at the beginning of the article. Around the centrepiece there are four oval plaques with "Passion emblems" and two plaques with plot compositions: "Descent from the Cross" (above) and "Entombement" (below) ${ }^{17}$.

The setting of the third Gospel, now preserved in the Russian Museum (fig. 15), dates back to $1681^{18}$. The codex was placed in the Archangel Cathedral of the Moscow Kremlin, as evidenced by a black inscription cut at the edge of the top cover:

17 About "Passion emblems" on these Gospels: [27, p. 586-7, 597-8, 601-2, ill. 1-2].

18 The State Russian Museum, Inv. No. БK-3126. Gold, silver, precious stones, glass; forging, casting, overlay casting, embossing, carving, gilding, blackening, enamel. $44 \times 26,5 \times 13$. Published: [25, p. 195, cat. 58 , ill. 56]. 


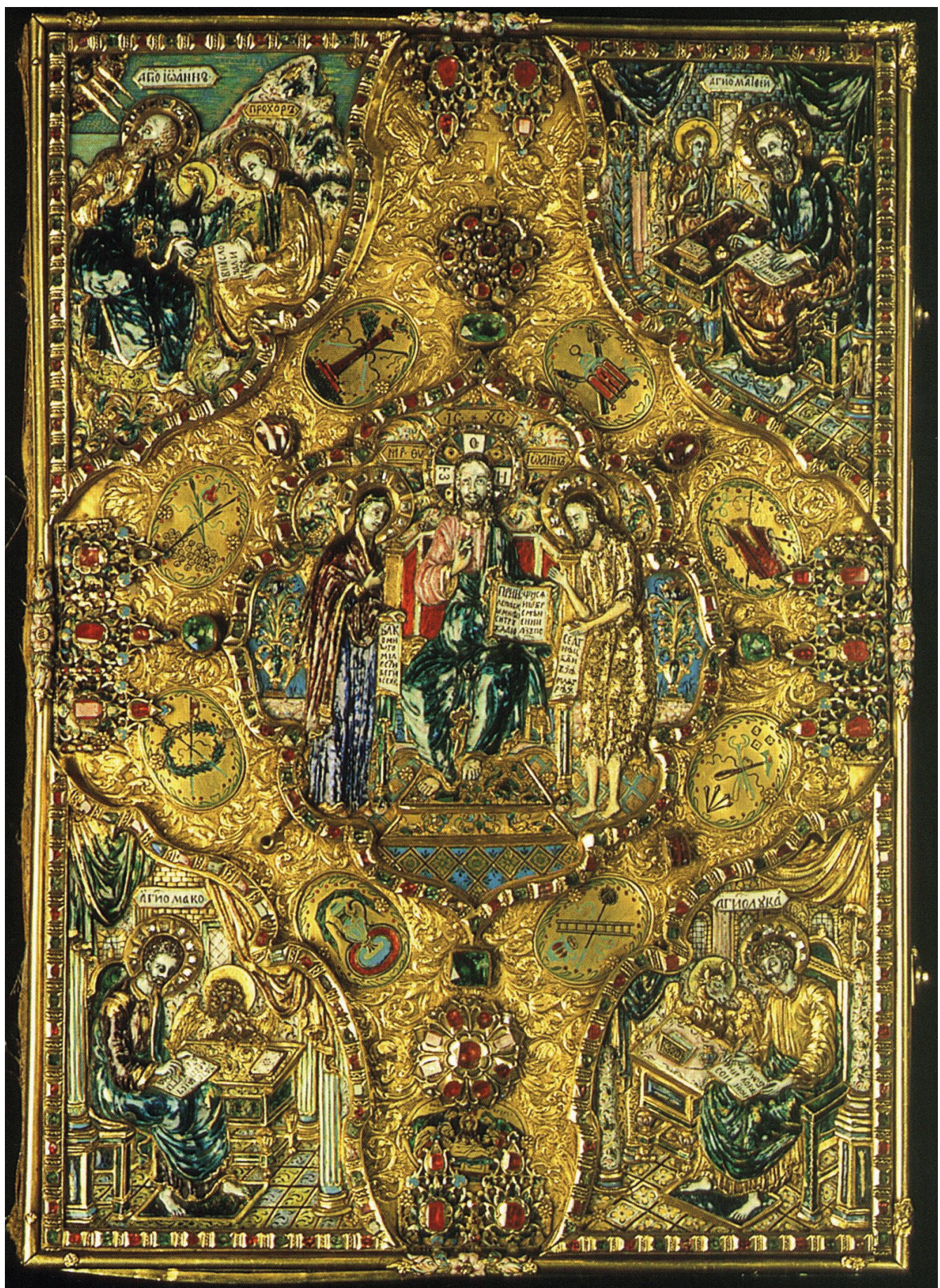

Fig. 14. Gospel Cover. Donation by Fyodor Alexeyevich toVerkhospassky Cathedral of the Moscow Kremlin. 1678. Moscow Kremlin Workshops. Moscow Kremlin Museums 


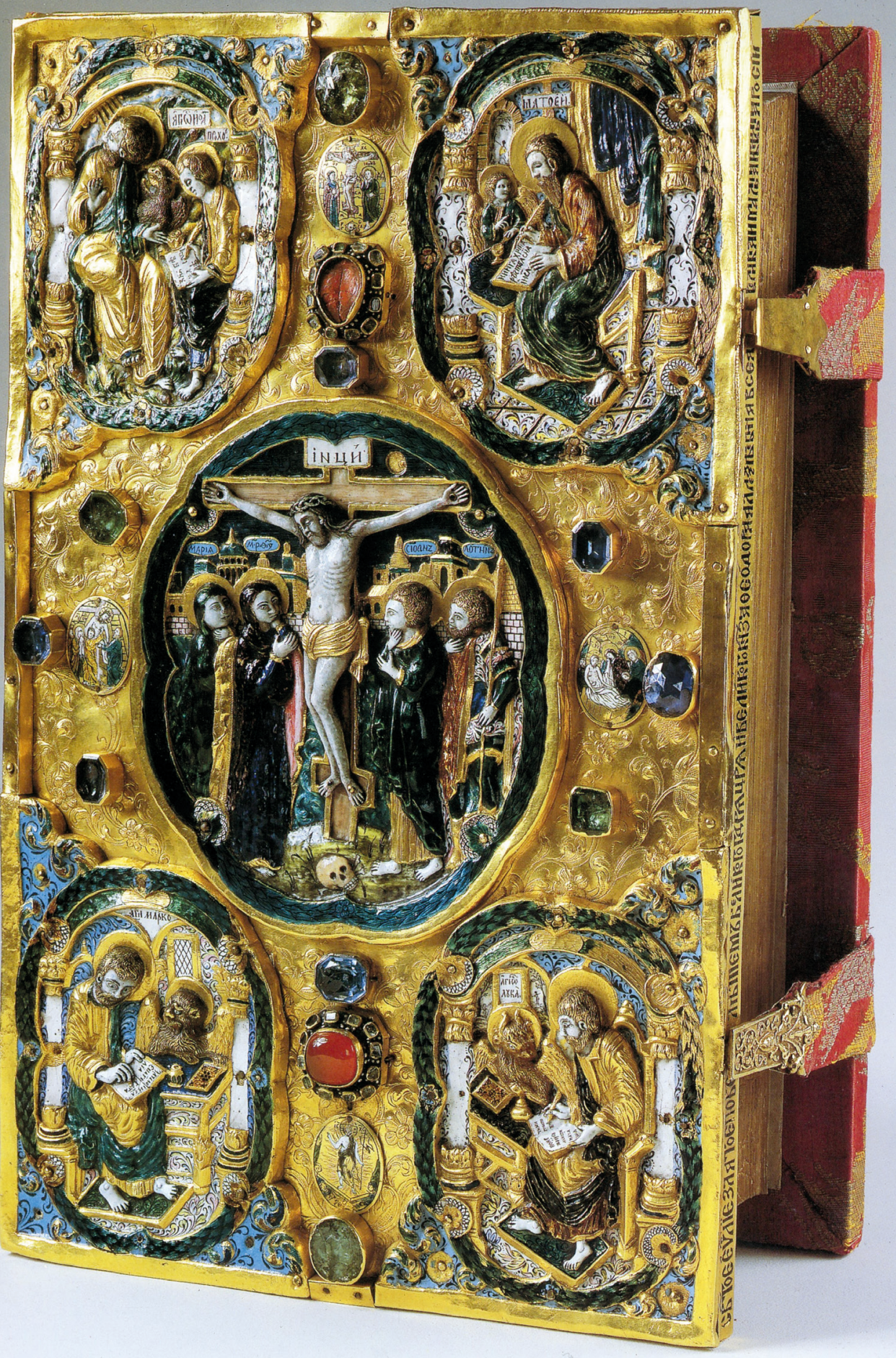

Fig. 15. Gospel Cover. Donation by Fyodor Alexeyevich to the Cathedral of the Archangel Michael, the Moscow Kremlin. 1681. Moscow Kremlin Workshops. State Russian Museum 


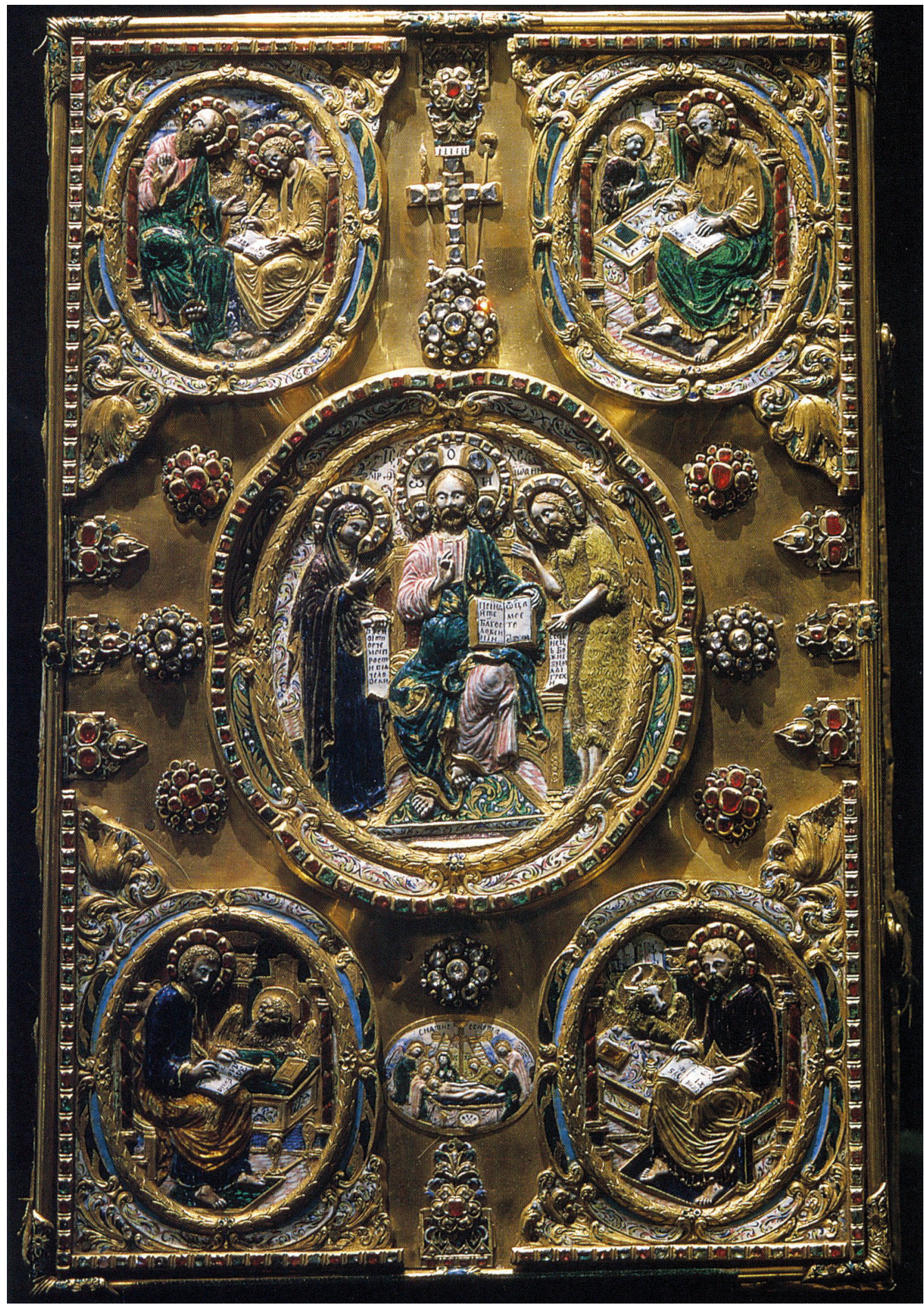

Fig. 16. Gospel Cover. Donation by Maria Alexeyevna to Simonov Monastery. 1683. Moscow Kremlin Workshops. Moscow Kremlin Museums 


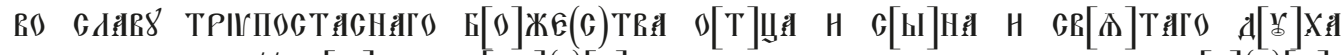

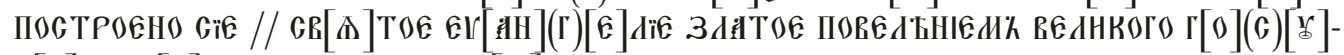

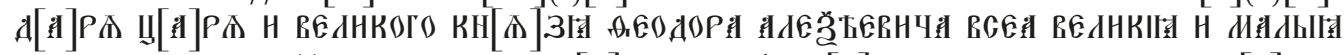

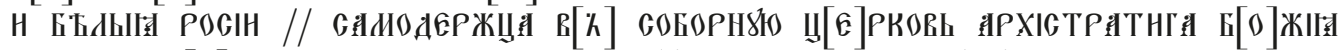

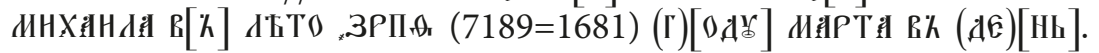

As well as on the Gospel's setting from the Church of the Resurrection, in the centre of the cover of the Gospel from the Cathedral of the Archangel Michael there is a high relief composition "The Crucifixion", painted with enamel. Four oval convex plaques, reinforced between the stones on either side of the centrepiece, are filled with enamel images of three episodes of the Passion - "The Crucifixion", "Descent from the Cross" and "Lamentation" - and the Resurrection of the Lord.

It is no wonder that the Gospel which was placed on $14^{\text {th }}$ August, 7191 (1683) "under the power" of the Tsars John and Peter Alexeyevich into the Simonov Monastery in Moscow by the Tsarevna and the Grand Duchess Maria Alexeyevna (fig. 16), as it was ordered "to eternal remembrance in the blessed assurance of his (brother) great sovereign, the Tsar and the Grand Duke Fyodor Alexeyevich". The middle of its upper cover was again decorated with an embossment of a three-figure Deesis, with the Golgotha cross above its frame, made up of small diamonds (?); as for the Passions, it was the composition "Lamentation - Entombement" ("Descent from the Cross" by inscription) that was chosen to be placed at the bottom of the cover between the evangelists Mark and Luka ${ }^{19}$. In 1684, the last Gospel was placed in the Arkhangelsk Cathedral of the Kremlin, the design of its setting fully corresponded with the examined typology. The depositor was Tsar Fyodor's widow, Marfa Matveyevna Apraksina. At this time the Arkhangelsk Cathedral had in its possession a Gospel with a relief enamelled Crucifix that had been donated to the church in 1681 by Fyodor Alekseyevich (see above), so the composition of the three-figure Deesis was chosen for the new Gospel centrepiece. Placed around it were six enamel plaques with "Passion emblems", and on the central axis between the evangelists there were an equal-ended cross and a plaque with "Lamentation" ${ }^{20}$. The fact that two similarly decorated Testaments were located in the same cathedral predetermined the fate of the earlier one. When the fortress church was established in Shlisselburg in 1703, Tsar Peter Alexeyevich ordered the precious gospel of Fyodor Alexeyevich to be sent to the new church. In the Shlisselburg fortress church in the name of the Nativity of John the Baptist the Testament was kept until 1910 when it was decided to re-locate it to the Fyodorovsky Cathedral in Tsarskoye Selo [29, p. 261; 30, p. КА (21), NД (54), ill. 31, p. 42, No. 590]. The Holy Testament was kept in this church until the Bolsheviks came to power, and then it was transferred to the Russian Museum for safekeeping.

19 State Moscow Kremlin Museums, Inv. No. KH-13. Size $41 \times 31$. Published: [26, p. 147-9, cat. 135]. M. V. Martynova suggested that the same masters took part in creating the setting that worked on the settings of 1678 for the Church of the Savior Not Made by Hands and the Church of the Resurrection.

20 The Testament suffered during the robbery of the Patriarch's sacristy by the Polezhaev brothers in 1918. Currently, the Museums of the Moscow Kremlin hold details of its setting. A photograph to give a general idea about the design of its setting is reproduced in the paper: [28, ill. between p. 41 and 42]. Publication of details on the setting and photographs from the paper by V. Trutovsky: [26, p. 152-3, cat. 137]. 


\section{References}

1. Zamyslovskii, Egor. Tsarstvovanie Fedora Alekseevicha. St. Petersburg: Tip. Zamyslovskago i Bobyleva, 1871, pt. 1. (In Russian)

2. Bogdanov, Andrei. Tsar' Fedor Alekseevich. 1676-1682. Moscow: Rossiiskoe Universitetskoe Izdatel'stvo, 1998. (In Russian)

3. Sedov, Pavel. Zakat Moskovskogo tsarstva. Tsarskii dvor kontsa XVII veka. St. Petersburg: Dmitrii Bulanin, 2006. (In Russian)

4. Sokolova, Irina. "Novyi Ierusalim v Kremle. Nezavershennyi zamysel tsaria Fedora Alekseevicha”. In Gosudarstvennyi istoriko-kul'turnyi muzei-zapovednik "Moskovskii Kreml”'. Materialy i issledovaniia. Khudozhestvennye pamiatniki Moskovskogo Kremlia, edited by Aleksei Levykin, 53-63. Moscow: FGU "GIKMZ 'Moskovskii Kreml””, 2003, iss. XVI. (In Russian)

5. Shchedrina, Kseniia. "Khramy-relikvarii evropeiskikh i russkikh monarkhov (Kremlevskii 'Novyi Ierusalim' tsaria Feodora Alekseevicha)" ["Palace Reliquary Cathedrals of Mediaeval European and Russian Monarchs ('New Jerusalem' in the Grand Terem Palace of Tzar Feodor Alexeevich)"]. In Iskusstvo khristianskogo mira, edited by Ariadna Voronova, 305-12. Moscow: Pravoslavnyi Sviato-Tikhonovskii bogoslovskii institut, 2003, iss. 7. (In Russian)

6. Anan'eva, Tat'iana. "Ikona 'Raspiatie' XVII v. iz fondov Russkogo muzeia" ["The XVIIth Century Icon 'Crucifixion' from the Fonds of State Russian Museum”]. In Pamiatniki kul'tury. Novye otkrytiia. Ezhegodnik [Monuments of Culture. New Discoveries], edited by Dmitrii Likhachev et al., 330-2. Leningrad: Nauka, 1979. (In Russian)

7. Sokolova, Irina "Reznoi skladen' tsaria Fedora Alekseevicha - pamiatnik russko-ukrainskikh sviazei vtoroi poloviny XVII veka” ["Tsar Fyodor Alekseevich's Carved Winged Altarpiece as a Monument of Russian-Ukrainian Relations in the $2^{\text {nd }}$ Half of XVII Century"]. In Iskusstvo khristianskogo mira, edited by Ariadna Voronova, 196-213. Moscow: Pravoslavnyi Sviato-Tikhonovskii bogoslovskii institut, 2004, iss. 8. (In Russian)

8. Sokolova, Irina. Ukrainskie reznye ikony i kresty XVII-XIX vekov. Katalog. Moscow: FGBUK "GIKMZ 'Moskovskii Kreml'”, 2013. (In Russian)

9. Mineia. Sentiabr'. Moscow: Izdatel'skii sovet Russkoi Pravoslavnoi Tserkvi, 2003. (In Russian)

10. Skaballanovich, Mikhail, ed. Khristianskie prazdniki. Vozdvizhenie chestnogo kresta. 6 bks. Kiev: Izd. zhurnala "Propovednicheskii listok", 1915, bk. 2. Reprint, Sviato-Troitskaia Sergieva Lavra, 1995. (In Russian)

11. Pavlenko, Alla. "Mikhail Miliutin — tsarskii izograf XVII veka". In Russkaia pozdniaia ikona ot XVII do nachala XX stoletiia, edited and compiled by Mikhail Krasilin, 153-8. Moscow: GosNIIR, 2001. (In Russian)

12. Kochetkov, Igor', ed., comp. Slovar' russkikh ikonopistsev XI-XVII vekov. Moscow: Indrik, 2003. (In Russian)

13. Vlasova, Tat'iana. "Istoriia formirovaniia ikonostasov Arkhangel'skogo sobora". In Arkhangel'skii sobor Moskovskogo Kremlia, edited and compiled by Natal'ia Maiasova, 220-58. Moscow: Krasnaia ploshchad', 2002. (In Russian)

14. Bekeneva, Nadezhda, comp. Simon Ushakov - tsarskii izograf. Moscow: Gos. Tret'iakovskaia galereia, 2015. (In Russian)

15. Chubinskaia, Valentina. "Ikona 'Raspiatie s apostol'skimi stradaniiami' 1697-1699 godov. Simvoliko-allegoricheskii zamysel v kontekste istoricheskikh sobytii”. In Gosudarstvennyi istoriko-kul'turnyi muzei-zapovednik "Moskovskii Kreml"'. Materialy i issledovaniia. Petr Velikii - reformator Rossii, edited by N. Vladimirskaia, 144-59. Moscow: GIKMZ "Moskovskii Kreml”, 2001, iss. XIII. (In Russian)

16. Izvekov, Nikolai. Moskovskie Kremlevskie dvortsovye tserkvi i sluzhivshie pri nikh litsa v XVII veke. Moscow: Pech. A.I. Snegirevoi, 1906. (In Russian)

17. Pivovarova, Nadezhda. "Deiatel'nost' Komissii 'pomgola' i postuplenie pamiatnikov tserkovnogo iskusstva v Gosudarstvennyi Russkii muzei v kontse 1920-kh - nachale 1930 gg." ["Activity of the 'Pomgol' (Aid against Famine) Committee and Entry of Monuments of Church Art into the State Russian Museum in Late 1920s - Early 1930s"]. In Problemy khraneniia i restavratsii jeksponatov $v$ khudozhestvennom muzee. Materialy nauchno-prakticheskogo seminara. 26-27 aprelia 2006 goda [Problems of Storage and Restoration of Exhibits in an Art Museum. Scientific-Practical Seminar. April 26-27, 2006], edited by Ivan Karlov, 9-17; 155-63. St. Petersburg: State Russian Museum, 2006. (In Russian, In English)

18. Pivovarova, Nadezhda. Pamiatniki tserkovnoi stariny v Peterburge - Petrograde - Leningrade. Iz istorii formirovaniia muzeinykh kollektsii. 1850-1930-e gody. Moscow: BuksMArt, 2014. (In Russian) 
19. Kuznetsova, Liliia. "O nekotorykh veshchakh iz riznitsy Bol'shogo sobora Zimnego dvortsa, peredannykh v 1920-e gody v sobranie Ermitazha" ["Some Pieces from the Sacristy of the Winter Palace Great Cathedral Passed to the Hermitage Collection in 1920s."]. In Gos. Ermitazh. Sobor Spasa Nerukotvornogo obraza $v$ Zimnem dvortse kak pamiatnik dukhovnoi i material'noi kul'tury. Materialy nauchnoi konferentsii [Cathedral of Our Saviour's Sacred Image in the Winter Palace as a Monument of Spiritual and Material Culture. Papers of the Scientific Conference], edited by Mikhail Anikin, 27-31. St. Petersburg: Gos. Ermitazh, 1998. (In Russian)

20. Kuznetsova, Liliia. "K voprosu o predmetakh utvari, ispolnennykh dlia Spasskogo i Voskresenskogo 'verkhovykh' soborov Kremlia v 1677-1679 gg." In Soobshcheniia Gosudarstvennogo Ermitazha [Reports of the State Hermitage Museum], edited by Mikhail Piotrovskii, 22-30. St. Petersburg: Gos. Ermitazh, 1999, iss. 58. (In Russian)

21. Baddlei, Oriana, Erlin Briunner, and Iurii Piatnitskii, eds. Sinai. Vizantiia. Rus'. Pravoslavnoe iskusstvo $s 6$ do nachala 20 veka. Katalog vystavki [Sinai, Byzantium, Russia. Orthodox Art from the Sixth to the Twentieth Century]. Translated by Anna Konivets and Anastasiia Mikliaeva. St. Petersburg: Gos. Ermitazh; Fond sviatoi Ekateriny, 2000.

22. Klimov, Pavel, comp. Religioznyi Peterburg. Al'manakh. St. Petersburg: Palace Editions, 2004, iss. 106.

23. Tsareva, T., comp. Russkoe serebro v sobranii Tverskogo muzeia. K 125-letiiu Tverskogo gosudarstvennogo ob"edinennogo muzeia. Katalog. Moscow: VRIB "Soiuzreklamkul'tura”, 1991. (In Russian)

24. Pivovarova, Nadezhda. "Russkie drevnosti v Tsarskosel'skom Arsenale: o sostave i istoriko-kul'turnom znachenii sobraniia". In Tsarskoe Selo na perekrestke vremen i sudeb. Materialy XVI Tsarskosel'skoi nauchnoi konferentsii, 153-61. 2 pts. St. Petersburg: GMZ “Tsarskoe Selo”, 2010, pt. 2. (In Russian)

25. Gos. Russkii muzei. Zolotaia kladovaia Russkogo muzeia. K 100-letiiu muzeia. 1898-1998. Compiled by Tat'iana Vilinbakhova et al. St. Petersburg: Palace Editions, 1998. (In Russian)

26. Martynova, Marina. Moskovskaia emal' XV-XVII vekov. Katalog. Moscow: FGU "GIKMZ 'Moskovskii Kreml'”, 2002. (In Russian)

27. Zvezdina, Iuliia. "Obrazy relikvii v strastnykh emblemakh na proizvedeniiakh russkogo iskusstva kontsa XVII veka" ["The Image of Relics in Emblems of the Passion in the Late-Seventeenth Century Russian Art"]. In Vostochnokhristianskie relikvii [Eastern Christian Relics], edited and compiled by Aleksei Lidov, 586-607, 599-600. Moscow: Progress-Traditsiia, 2003. (In Russian)

28. Trutovskii, Vladimir. "Romanovskaia' tserkovno-arkheologicheskaia vystavka v Moskve". Starye gody, June (1913): 1-8. (In Russian)

29. Istoriko-statisticheskie svedeniia o S.-Peterburgskoi eparkhii. Izdanie S.-Peterburgskogo eparkhial'nogo istoriko-statisticheskogo komiteta. 10 issues. St. Petersburg: Tip. Departamenta udelov, 1884, iss. 8. (In Russian)

30. Feodorovskii Gosudarev sobor v Tsarskom Sele. Peshchernyi khram vo imia prepodobnogo Serafima Sarovskogo Chudotvortsa. [Tsarskoe Selo]: Izdanie Feodorovskogo Gosudareva sobora, [1915], iss. 1. (In Russian)

31. Tserkovnaia i riznichnaia opis' tserkvi vo imia prepodobnogo Serafima Sarovskogo Chudotvortsa, pri Sobstvennom Ego Imperatorskogo Velichestva Svodnom pekhotnom polku, v gor. Tsarskom Sele. St. Petersburg: Sinodal'naia tipografiia, 1912. (In Russian)

\section{Sources}

I. State Russian Archives of History. Stock 1088. Inventory 3. Record 1334. (In Russian)

Received: June 01, 2018

Accepted: August 30, 2018

Author's information:

Nadezhda V.Pivovarova — PhD; nad-pivovarova@yandex.com 


\title{
Произведения московских художественных мастерских периода правления царя Федора Алексеевича: к постановке проблемы
}

\author{
Н.В. Пивоварова \\ Государственный Русский музей, \\ Российская Федерация, 191186, Санкт-Петербург, ул. Инженерная, 4
}

Для цитирования: Pivovarova, Nadezhda. "Works of Moscow Art Workshops During the Reign of Tsar Fyodor Alexeyevich: Defining the Issue". Вестник Санкт-Петербургского университета. Искусствоведение 8, no. 4 (2018): 646-65. https://doi.org/10.21638/spbu15.2018.407

В статье изложены результаты работы по изучению произведений московских царских мастерских в непродолжительный период правления царя Федора Алексеевича (16761682). Анализируются история создания, иконография и художественные особенности некоторых произведений искусства из фондов петербургских и московских музеев. Основное внимание уделяется иконографической программе и надписи на иконе «Распятие с апостолами и святыми» из собрания Русского музея в Санкт-Петербурге. Содержание надписи и колористическое решение иконы позволили ее первому и единственному исследователю Т.Ананьевой определить «житейский смысл» иконы, которая, по ее мнению, была создана для царя Федора Алексеевича и отразила радость в связи с избавлением от тягот войны и установлением мира. Возможным автором текста надписи Т. Ананьева считала Иоанна Максимовича, искавшего помощи Москвы в годы военного противоборства Заднепровской Малороссии и Турции. Новое обращение к надписи дало возможность опровергнуть предложенную версию. Установлено, что текст не является оригинальным произведением, а заимствован из службы праздника Воздвижения креста (14 сентября). Определение источника текста служит веским основанием для переосмысления идейного замысла иконы. Автор обосновывает гипотезу о связи иконы с проектом устройства в царствование Федора Алексеевича «Нового Иерусалима» в Московском Кремле. Высказывается мнение о создании иконы группой мастеров под руководством ведущего изографа Оружейной палаты Михаила Милютина. Для анализа привлекаются также два литургических прибора и несколько напрестольных Евангелий, происходящих из домовых церквей Теремного дворца Московского Кремля. Автор рассматривает особенности их техники и устанавливает отличия в художественном оформлении.

Ключевые слова: царь Федор Алексеевич, домовые церкви, Московский Кремль, московские мастерские.

Контактная информация:

Пивоварова Надежда Валерьевна - канд. искусствоведения; nad-pivovarova@yandex.com 